\title{
Penetapan Metode Ekstraksi Kalium Terbaik untuk Tanaman Tomat (Solanum lycopersicum L.) pada Tanah Andisol
}

\author{
Determination of the Best Potassium Extraction Method for Tomato \\ (Solanum lycopersicum L.) on Andisols Soil
}

Endang Gunawan ${ }^{1,2^{*}}$, Anas D. Susila ${ }^{1,3}$, Atang Sutandi ${ }^{4}$, dan Edi Santosa ${ }^{3}$

Diterima12 Maret 2019/Disetujui 21 Oktober 2019

\begin{abstract}
Determination of recommendations for potassium $(K)$ based on soil tests for tomato in Andisol is rarely studied in Indonesia. This experiment was started by making of $K$ soil status in IPB Research Station Pasirsarongge Ciputri Cianjur and followed by correlation test in PKHT IPB greenhouse Tajur Bogor West Java, from Desember 2015 to May 2016. The objective of the experiment was to select the best extraction method of $K$ for tomato on Andisol soil. The experiment used single location approach with randomized block design. The treatmens is soil $K$ status by application of $\mathrm{K}_{2} \mathrm{SO}_{4}$ solutionwith five rate of $\mathrm{K}: 0,1 / 4, X, 1 / 2 X, 3 / 4 X$, and $X . X$ was $K$ rate of $413.4 \mathrm{~kg} \mathrm{~K}$ $h a^{-1}$ were applied to achieve maximum $K$ concentration in the soil and incubated for 4 months to obtain different $\mathrm{K}$ nutrient status. Analysis of soil K using five extraction methods: Bray 1, $\mathrm{HCl} 25 \%$, Morgan Wolf, Mechlich and NH4OAc. The results showed the differences in response of plant height and biomass dry weight to nutrient status of Andisols K. Quadratic response was shown in plant height at 6 and 7 weeks after planting and biomass dry weight. The best $K$ extraction method was $\mathrm{NH}_{4} \mathrm{OAc}$ with correlation coefficient $(r)$ of 0.75 .
\end{abstract}

Key words: biomass, extraction method, $\mathrm{K}$ status, $\mathrm{K}_{2} \mathrm{SO}_{4}, \mathrm{NH}_{4} \mathrm{Oac}$

\begin{abstract}
ABSTRAK
Penetapan rekomendasi dosis kalium (K) berdasarkan uji tanah untuk tanaman tomat pada tanah Andisol belum banyak dikaji di Indonesia. Penelitian diawali dengan pembuatan status hara $\mathrm{K}$ tanah di Kebun Percobaan IPB Pasirsarongge Ciputri Cianjur dilanjutkan dengan uji korelasi di rumah plastik PKHT IPB Tajur Bogor pada Desember 2015 sampai Mei 2016. Tujuan penelitian adalah menetapkan metode ekstraksi $\mathrm{K}$ terbaik bagi tanaman tomat di tanah Andisol. Status $\mathrm{K}$ tanah dibuat dengan larutan kalium sulfat $\left(\mathrm{K}_{2} \mathrm{SO}_{4}\right)$ sebesar $0,1 / 4 \mathrm{X}, 1 / 2 \mathrm{X}, 3 / 4 \mathrm{X}$, dan $\mathrm{X}$ dimana $\mathrm{X}$ adalah 413.4 $\mathrm{kg} \mathrm{K} \mathrm{ha}{ }^{-1}$ sebagai dosis $\mathrm{K}$ maksimum yang ditambahkan untuk mencapai kadar K maksimum dalam larutan tanah. Larutan $\mathrm{K}_{2} \mathrm{SO}_{4}$ disiramkan merata pada bedengan tanah dan diinkubasi selama 4 bulan. Ekstraksi $\mathrm{K}$ tanah menggunakan 5 metode yaitu: Bray $1(\mathrm{HCl} 5 N), \mathrm{HCl} 25 \%$, Morgan Wolf $\left(\mathrm{NaC}_{2} \mathrm{H}_{3} \mathrm{O}_{2} \cdot 3 \mathrm{H}_{2} \mathrm{O}\right)$, Mechlich ( $\left.\mathrm{HCl} 0.05 N+\mathrm{H}_{2} \mathrm{SO}_{4} 0.025 N\right)$ dan $\mathrm{NH}_{4} \mathrm{OAc}\left(\mathrm{NH}_{4} \mathrm{OAc}, \mathrm{pH}\right.$ 7). Hasil penelitian menunjukkan adanya perbedaan respon tinggi tanaman, bobot kering biomas, kandungan $\mathrm{K}$ tanaman terhadap tingkat status hara $\mathrm{K}$ tanah. Pola respon kuadratik ditunjukkan pada tinggi tanaman umur 6 dan 7 minggu setelah tanam, dan bobot kering total. Metode ekstraksi K Andisols terbaik untuk tomat adalah $\mathrm{NH}_{4} \mathrm{OAc}$ dengan nilai koefisien korelasi (r): 0.75 .
\end{abstract}

Kata kunci: biomas, $\mathrm{K}_{2} \mathrm{SO}_{4}$, metode ekstraksi, $\mathrm{NH}_{4} \mathrm{Oac}$, status $\mathrm{K}$

\footnotetext{
${ }^{1}$ Pusat Kajian Hortikultura Tropika, Institut Pertanian Bogor

J1. Raya Pajajaran Kampus IPB Baranangsiang, Bogor 16144, Jawa Barat.

${ }^{2}$ Program Studi Agronomi dan Hortikultura, Sekolah Pascasarjana Institut Pertanian Bogor

Jl. Meranti Kampus IPB Darmaga, Bogor 16680, Jawa Barat.

${ }^{3}$ Departemen Agronomi dan Hortikultura, Institut Pertanian Bogor

Jl. Meranti Kampus IPB Darmaga, Bogor 16680, Jawa Barat.

${ }^{4}$ Departemen Ilmu Tanah dan Sumberdaya Lahan, Institut Pertanian Bogor

J1. Meranti Kampus IPB Darmaga, Bogor 16680, Jawa Barat.

E-mail: mandezfarm@gmail.com (*Penulis korespondensi)
} 


\section{PENDAHULUAN}

Andisol adalah jenis tanah produktif di Indonesia yang berkembang dari bahan vulkanik yang umumnya terdapat di dataran tinggi. Luas tanah Andisol di Indonesia mencapai 5.39 juta ha setara dengan $2.9 \%$ dari total tanah pertanian yang berasal dari bahan vulkanik (Sukarman dan Dariah, 2014). Wilayah tanah Andisol dikenal sebagai sentra utama komoditas tanaman tomat (Solanum lycopersicum L.) di dataran menengah dan tinggi (Ditjen Horti, 2017).

Ketersediaan hara $\mathrm{K}$ yang rendah pada tanah andisol (Sari et al., 2013) menjadi masalah untuk budidaya tanaman tomat. Ketersediaan hara K yang rendah menyebabkan produktivitas tanaman dan kualitas buah tomat yang rendah. Produktivitas tomat di Indonesia hanya 15-17 ton ha ${ }^{-1}$ (Ditjen Horti, 2017), jauh lebih rendah dari potensinya yakni 40-60 ton ha ${ }^{-1}$ (Purwati, 2009). Hara K tanah yang rendah dilaporkan menurunkan ketahanan tanaman terhadap cekaman lingkungan dan serangan penyakit layu Ralstonia solanacearum juga menyebabkan gejala Bloachyripening dan Yellow shoulder (matang tidak sempurna) pada pangkal buah sehingga dapat menurunkan kualitas buah tomat (Maynard et al., 2016; Zhang et al., 2018). Pemupukan $\mathrm{K}$ dapat meningkatkan kualitas buah yaitu total padatan terlarut dan total asam tertitrasi pada tomat (Nurtika, 2009) dan melon (Huda et al., 2018).

Upaya pemupukan K pada tanah Andisol meningkatkan produksi tomat sudah dilakukan, tetapi belum memuaskan karena penentuan dosis pupuk K yang belum tepat. Akibatnya, dosis $\mathrm{K}$ antar petani sangat bervariasi yakni 50$300 \quad \mathrm{~K}_{2} \mathrm{O} \quad \mathrm{kg} \mathrm{ha}^{-1}$ (Kasno et al., 2013). Pemberian pupuk $\mathrm{K}$ yang tidak tepat selain kurang efektif dan tidak ekonomis, juga dapat meningkatkan pencemaran lingkungan (Suganda dan Nurida, 2013; Faranso dan Susila, 2015). Sangat beragamnya variasi rekomendasi pemupukan mengakibatkan produksi cabai (Widyanti dan Susila, 2015) dan sayuran lainnya (Izhar et al., 2012) di Indonesia belum maksimal. Idealnya, penetapan dosis rekomendasi didasarkan pada hasil analisis tanah dan tanaman yang dilakukan sebelum penanaman tomat. Tetapi cara tersebut relatif mahal dan dapat membebani biaya produksi, oleh karena itu, diperlukan metode ekstraksi yang unggul untuk menentukan dosis rekomendasi secara umum untuk tanah Andisol sebagai panduan bagi praktisi.

Setiap jenis tanah dan tanaman tertentu memiliki kekhasan metode ekstraksi yang mencerminkan ketersediaan hara bagi tanaman tersebut; Truogh, Colwell, dan Bray 1 digunakan untuk tanaman jagung di Inceptisols (Syafruddin, 2008), Mechlich I untuk tomat di Inceptisols (Izhar et al., 2013) dan Bray1, Olsen dan Mechlich untuk tanaman cabai di tanah Inceptisols (Amisnaipa et al., 2014). Hipotesis penelitian ini adalah bahwa tanaman tomat pada tanah Andisol membutuhkan metode ekstraksi hara $\mathrm{K}$ yang berbeda. Penelitian uji tanah penting dilakukan dengan tujuan: (a) membuat status hara $\mathrm{K}$ tanah yang berbeda pada tanah Andisol, (b) menguji beberapa metode ekstraksi $\mathrm{K}$ tanah, dan (c) menetapkan metode ekstraksi K terbaik untuk tanaman tomat pada tanah Andisol.

\section{BAHAN DAN METODE}

\section{Percobaan I. Pembuatan Status Hara K Tanah Andisol}

Pembuatan status hara $\mathrm{K}$ tanah dilaksanakan di lahan Kebun Percobaan IPB Pasirsarongge, Pacet, Cianjur, Jawa Barat 6.766687 LS, 107.0500 BT; 1100 meter di atas permukaan laut (m dpl) pada Desember 2015 sampai Mei 2016. Jenis tanah di kebun percobaan adalah tanah ordo Andisol, sub ordo Aquands, grup Melanaquands dan sub grup Thaptic Melanaquands (Soil Survey Staf, 2014). Lahan yang digunakan berupa tanah bera selama 10 tahun.

Lahan dibersihkan dari gulma dan sampah, kemudian diolah sedalam $25-30 \mathrm{~cm}$ dua kali secara manual dengan selang antar pengolahan 2 minggu. Selanjutnya dibuat bedengan ukuran $1.5 \mathrm{~m} \times 25 \mathrm{~m} \times 0.4 \mathrm{~m}$ (lebar $\times$ panjang $\times$ tinggi) sebagai satuan petak percobaan.

Perlakuan penjenuhan $\mathrm{K}$ dimaksudkan untuk mendapatkan status $\mathrm{K}$ tanah dari sangat rendah sampai sangat tinggi. Penjenuhan $\mathrm{K}$ tanah dilakukan menggunakan pupuk kalium sulfat $\left(\mathrm{K}_{2} \mathrm{SO}_{4}\right)$ yang dilarutkan dalam air, dengan lima dosis yaitu : sangat rendah (0X), rendah $(1 / 4 X)$, sedang $(1 / 2 X)$, tinggi $(3 / 4 X)$, dan sangat tinggi $(\mathrm{X})$. Nilai $\mathrm{X}$ merupakan penambahan dosis pupuk $\mathrm{K}$ untuk mencapai 


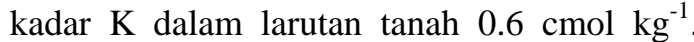
Nilai $\mathrm{X}$ yang digunakan untuk mencapai kadar $\mathrm{K}$ dalam larutan tanah maksimum adalah $413.4 \mathrm{~kg} \mathrm{~K} \mathrm{ha}^{-1}$ setara dengan $996.4 \mathrm{~kg}$ pupuk $\mathrm{K}_{2} \mathrm{SO}_{4}$ ha $^{-1}$ atau $3.74 \mathrm{~kg}$ pupuk $\mathrm{K}_{2} \mathrm{SO}_{4}$ petak $^{-1}$.

Dosis tersebut setara dengan pemberian: $0,0.93,1.87,2.80$ dan $3.74 \mathrm{~kg}$ pupuk $\mathrm{K}_{2} \mathrm{SO}_{4}$ petak $^{-1}$. Untuk memudahkan aplikasi, masingmasing dosis pupuk $\mathrm{K}_{2} \mathrm{SO}_{4}$ dilarutkan dalam air hingga mencapai 100 liter, dan disiramkan merata ke seluruh permukaan petakan. Selanjutnya, lahan diinkubasi selama 4 bulan. Setiap 2 minggu dilakukan pengadukan tanah sedalam $25-30 \mathrm{~cm}$. Setiap dosis menggunakan satu petak lahan.

Setelah inkubasi, diamati status hara K tanah. Sampel tanah diambil dari setiap petak dan dianalisis menggunakan lima metode ekstraksi yaitu: Bray $1(\mathrm{HCl} 5 N), \mathrm{HCl} 25 \%$, Morgan Wolf $\left(\mathrm{NaC}_{2} \mathrm{H}_{3} \mathrm{O}_{2} \cdot 3 \mathrm{H}_{2} \mathrm{O}\right)$, Mechlich ( $\mathrm{HCl} 0.05 \mathrm{~N}+\mathrm{H}_{2} \mathrm{SO}_{4} 0.025 \mathrm{~N}$ ) dan $\mathrm{NH}_{4} \mathrm{OAc}$ $\left(\mathrm{NH}_{4} \mathrm{OAc} ; \mathrm{pH} 7\right)$. Analisis karakteristik tanah sebelum penelitian dilakukan di Laboratorium Balai Penelitian Tanah Kementerian Pertanian Republik Indonesia, Bogor.

\section{Percobaan II. Uji korelasi $K$ dengan Pertumbuhan Tanaman Tomat}

Uji korelasi K tanah Andisol dilaksanakan pada Juni sampai Agustus 2016 di Rumah Kasa Kebun Percobaan PKHT IPB Tajur, Bogor, Jawa Barat (-6.636978 LS,106.823456 BT; 363 m dpl). Tanah hasil inkubasi pada Percobaan I diambil setiap petak setara $100 \mathrm{~kg}$ dengan cara zigzag (pola W), lalu dibersihkan dari akar dan pengotor lainnya, diaduk hingga merata dan dikeringanginkan selama 1 minggu. Kemudian diayak dan ditimbang seberat masing-masing $10 \mathrm{~kg}$ untuk dimasukkan ke dalam polibag.

Penelitian menggunakan rancangan acak kelompok (RAK) dengan satu faktor yakni lima taraf status hara K. Setiap taraf diulang lima kali, sehingga terdapat 25 satuan percobaan. Setiap satuan percobaan terdiri atas 5 polibag dengan ukuran $20 \mathrm{~cm} \times 35 \mathrm{~cm}$.

Tanaman tomat menggunakan varietas Marta F1 (PT. EWSI) umur 21 hari setelah semai. Bibit tomat ditanam satu tanaman per polibag. Pupuk dasar non perlakuan diberikan berupa urea sebanyak $46 \mathrm{~kg} \mathrm{~N}^{-1}$ dan SP36 sebanyak $39 \mathrm{~kg} \mathrm{P} \mathrm{ha}^{-1}$ (Amisnaipa et al., 2009). Seluruh dosis pupuk $\mathrm{P}$ dan $1 / 3$ dosis $\mathrm{N}$ diberikan seminggu sebelum tanamdan sisa $2 / 3$ dosis $\mathrm{N}$ diberikan pada 3 minggu setelah tanam (MST). Pemeliharaan, penyiraman, pengendalian hama penyakit dan pengendalian gulma dilakukan sesuai kebutuhan.

Peubah yang diamati adalah tinggi tanaman $(\mathrm{cm})$, bobot kering tajuk, akar dan total, serta kandungan $\mathrm{K}$ tanaman. Pengukuran tinggi tanaman dilakukan dari permukaan tanah sampai pucuk tertinggi pada umur 2, 3, 4, 5, 6 dan 7 MST. Bobot kering diamati dengan cara memisahkan bagian akar dan tajuk, lalu dikeringanginkan dan dioven pada suhu $70{ }^{\circ} \mathrm{C}$ selama 2-4 hari. Kandungan K tajuk kering oven, dan $\mathrm{K}$ tanah dianalisis di Laboratorium Kimia dan Kesuburan Tanah Departemen Ilmu Tanah dan Sumberdaya Lahan, Fakultas Pertanian, IPB.

Pengaruh perlakuan status hara $\mathrm{K}$ tanah terhadap respons tanaman diketahui melalui analisis sidik ragam. Jika perlakuan berpengaruh nyata dilanjutkan dengan uji polinomial ortogonal untuk mengetahui pola kurva respon. Metode ekstraksi terbaik ditentukan dari nilai koefisien korelasi ( $\mathrm{r}$ ) nyata antara $\mathrm{K}$ terekstrak (X) dan hasil tanaman relatif (Y). Kriteria pengekstrak terbaik adalah metode ekstraksi yang mempunyai nilai koefisien korelasi tertinggi dan nyata pada taraf 5\% (Kasno dan Suastika, 2017)

\section{HASIL DAN PEMBAHASAN}

\section{Status dan Respon Tanah terhadap Pemberian K}

Secara umum, tanah Andisol di lokasi penelitian memiliki status $\mathrm{K}$ potensial yang rendah dengan hara $\mathrm{K}$ yang dapat dipertukarkan sangat rendah (Tabel 1). Kondisi tersebut cukup ideal untuk membuat status hara $\mathrm{K}$ bertingkat dari rendah sampai tinggi.

Penambahan pupuk K berkorelasi positif meningkatkan nilai hara $\mathrm{K}$ tanah terekstrak oleh lima larutan pengekstrak (Gambar 1). Hal ini menunjukkan bahwa inkubasi 4 bulan cukup untuk penetapan status hara $\mathrm{K}$ tanah Andisol. Setiap larutan pengekstrak menunjukkan status hara $\mathrm{K}$ yang berbeda. Pengekstrak $\mathrm{NH}_{4} \mathrm{OAC}$ menunjukkan nilai korelasi tertinggi dalam menganalisis kandungan hara $\mathrm{K}$ tanah Andisol Pasirsarongge. Hal tersebut menunjukkan bahwa pemilihan metode ekstraksi akan menentukan definisi tingkat kecukupan K pada tanah Andisol. 
Tabel 1. Hasil analisis kimia dan fisika tanah Andisol Pasirsarongge Ciputri, Cianjur, Jawa Barat tahun 2016

\begin{tabular}{|c|c|c|}
\hline Karakteristik & Indeks Pengukuran $(*)$ & Metode \\
\hline Tekstur (\%) & & Pipeline \\
\hline pasir : debu : liat & $37: 34: 29$ & - \\
\hline $\mathrm{pH}$ & & $\mathrm{pH}$ meter \\
\hline $\mathrm{H}_{2} \mathrm{O}$ & 5.1 (masam) & - \\
\hline $\mathrm{KCl}$ & 4.8 (masam) & - \\
\hline \multicolumn{3}{|l|}{ Bahan organik } \\
\hline C-org (\%) & 4.48 (tinggi) & Walkley and Black \\
\hline $\mathrm{N}-\operatorname{org}(\%)$ & 0.35 (sedang) & Kjeldahl \\
\hline $\mathrm{C} / \mathrm{N}$ & 13 (sedang & - \\
\hline$P$ tersedia (ppm) & 15 (rendah) & Bray-1 \\
\hline P potensial $(\mathrm{mg} / 100 \mathrm{~g})$ & 310 (sangat tinggi) & $\mathrm{HCl} 25 \%$ \\
\hline $\mathrm{K}_{2} \mathrm{O}$ potensial $(\mathrm{ppm})$ & 17 (rendah) & $\mathrm{HCl} 25 \%$ \\
\hline \multicolumn{3}{|l|}{ Nilai tukar kation } \\
\hline $\mathrm{Ca}\left(\mathrm{cmol} \mathrm{kg}^{-1}\right)$ & 13.54 (tinggi) & $\mathrm{CH} 3 \mathrm{COONH} 41 \mathrm{MpH} 7$ \\
\hline $\mathrm{Mg}\left(\mathrm{cmol} \mathrm{kg}^{-1}\right)$ & 1.28 (sedang) & CH3COONH4 1M pH 7 \\
\hline $\mathrm{K}\left(\mathrm{cmol} \mathrm{kg}^{-1}\right)$ & 0.07 (sangat rendah) & $\mathrm{CH} 3 \mathrm{COONH} 41 \mathrm{MpH} 7$ \\
\hline $\mathrm{Na}\left(\mathrm{cmol} \mathrm{kg}^{-1}\right)$ & 0.33 (rendah) & $\mathrm{CH} 3 \mathrm{COONH} 41 \mathrm{MpH} 7$ \\
\hline KTK & 22.26 (sedang) & $\mathrm{CH} 3 \mathrm{COONH} 41 \mathrm{MpH} 7$ \\
\hline Kejenuhan basa (\%) & 43.58 (sedang) & - \\
\hline $\mathrm{Al}\left(\mathrm{cmol} \mathrm{kg}^{-1}\right)$ & 0.06 & $\mathrm{KCl} 1 \mathrm{M}$ \\
\hline $\mathrm{H}\left(\mathrm{cmol} \mathrm{kg}^{-1}\right)$ & 0.14 & $\mathrm{KCl} 1 \mathrm{M}$ \\
\hline
\end{tabular}

Keterangan: Sumber: hasil analisis di Laboratorium Balai Peneltian Tanah (2016). ${ }^{*}$ berdasarkan kriteria Balittanah (2005).
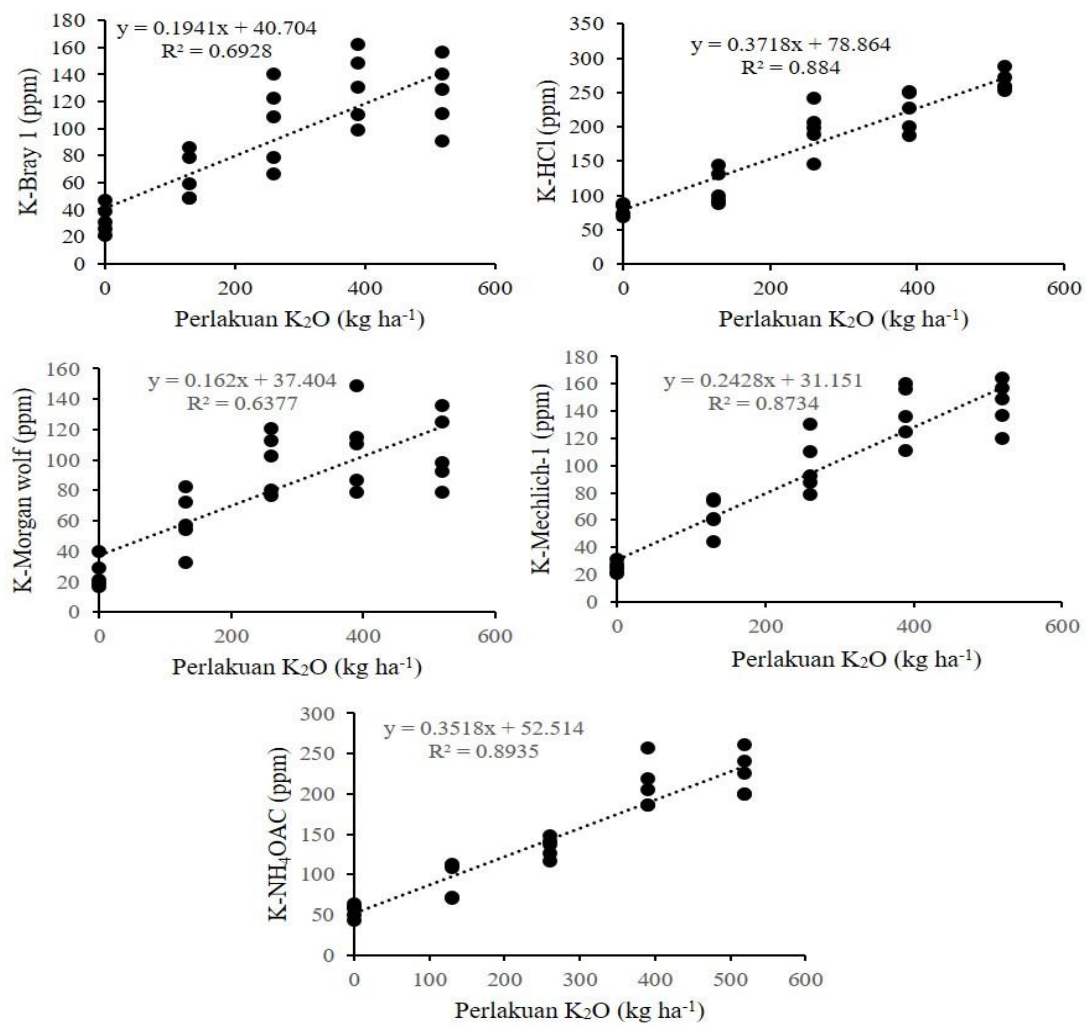

Gambar 1. Hubungan antara ekstraksi K-Bray $1, \mathrm{HCl} 25 \%$, Morgan Wolf, Mechlich 1 dan $\mathrm{NH}_{4} \mathrm{OAc}$ dengan perlakuan $\mathrm{K}_{2} \mathrm{SO}_{4}\left(\mathrm{~kg} \mathrm{~K}_{2} \mathrm{O} \mathrm{ha}^{-1}\right)$. 


\section{Respon Tanaman pada Status K Tanah}

Hasil Analisis Sidik Ragam (ANOVA) menunjukkan perlakuan status $\mathrm{K}$ tanah berpengaruh sangat nyata terhadap tinggi tanaman pada 4-7 MST (Tabel 2). Pertumbuhan tinggi tanaman tomat pada 4-5 MST meningkat secara linier sejalan dengan peningkatan status $\mathrm{K}$ tanah. Namun, pada 6 dan 7 MST pertumbuhan tinggi tanaman meningkat secara kuadratik terhadap peningkatan status $\mathrm{K}$ tanah. Pertumbuhan tinggi tanaman tomat meningkat seiring dengan peningkatan status $\mathrm{K}$ tanah dengan penambahan pupuk $\mathrm{K}$, konsisten dengan hasil penelitian tanaman tomat pada tanah Inceptisol (Amisnaipa et al., 2009).

Hasil penelitian menunjukkan status $\mathrm{K}$ tanah berpengaruh sangat nyata terhadap bobot kering akar, dan nyata terhadap bobot kering tajuk dan bobot kering total tanaman tomat (Tabel 3). Status K tanah berkorelasi positif dengan bobot kering tajuk, bobot kering akar dan bobot kering total tanaman. Peningkatan status $\mathrm{K}$ tanah menghasilkan peningkatan yang kuadratik pada bobot kering tajuk dan bobot kering total. Sedangkan bobot kering akar meningkat secara linier terhadap peningkatan status K tanah.

Status $\mathrm{K}$ tanah berkorelasi positif dengan serapan hara $\mathrm{K}$ oleh tanaman (Tabel 3). Hal ini mengindikasikan, peningkatan status hara $\mathrm{K}$ tanah sampai batas tertentu mampu meningkatkan ketersediaan hara $\mathrm{K}$ yang dapat diserap oleh tanaman tomat. Hal tersebut terkonfirmasi oleh kandungan $\mathrm{K}$ dalam jaringan tanaman sebagai indikator jumlah hara $\mathrm{K}$ yang diserap tanaman, juga meningkat (Gambar 2). Hasil analisis juga menunjukkan bahwa peningkatan kandungan $\mathrm{K}$ jaringan tanaman sejalan dengan peningkatan bobot kering tajuk.

Tabel 2. Nilai tengah dan respon tinggi tanaman tomat pada 1, 2, 3, 4, 5 , 6 dan 7 MST di Tajur, Bogor pada berbagai status K tanah Andisols asal Pasirsarongge Cianjur

\begin{tabular}{|c|c|c|c|c|c|c|c|}
\hline \multirow{2}{*}{$\begin{array}{l}\text { Status K Tanah } \\
\text { dengan Penambahan } \\
\mathrm{K}_{2} \mathrm{SO}_{4}\left(\mathrm{~kg} \mathrm{~K} \mathrm{ha}^{-1}\right) \\
\end{array}$} & \multicolumn{7}{|c|}{ Tinggi Tanaman $(\mathrm{cm})$} \\
\hline & 1 & 2 & 3 & 4 & 5 & 6 & 7 \\
\hline & & &.. $\operatorname{ming}$ & etelah t: & $\mathrm{n}(\mathrm{MS})$ & & \\
\hline 0 & 7.71 & 17.21 & 22.21 & 27.21 & 33.98 & 45.12 & 54.83 \\
\hline $103.4(1 / 4 x)$ & 5.17 & 13.51 & 19.51 & 24.76 & 38.76 & 49.95 & 69.81 \\
\hline $206.7(1 / 2 x)$ & 8.53 & 18.54 & 23.44 & 28.94 & 42.45 & 54.64 & 82.24 \\
\hline $310(3 / 4 x)$ & 5.91 & 15.14 & 21.46 & 27.46 & 47.80 & 64.85 & 96.91 \\
\hline $413.4(\mathrm{X})$ & 7.83 & 16.98 & 22.50 & 29.50 & 55.03 & 58.41 & 89.35 \\
\hline Respon & tn & tn & tn & $\mathrm{L}^{* *}$ & $\mathrm{~L}^{* *}$ & $\mathrm{~L}^{* *} \mathrm{Q} * *$ & $\mathrm{~L}^{* *} \mathrm{Q} * *$ \\
\hline
\end{tabular}

Tabel 3. Nilai tengah dan respon bobot kering biomasa tanaman tomat di Tajur, Bogor pada berbagai status K tanah Andisol asal Pasirsarongge

\begin{tabular}{lccc}
\hline Status $\mathrm{K}$ Tanah dengan & Penambahan & \multicolumn{3}{c}{ Bobot Kering $(\mathrm{g})$} \\
\cline { 2 - 4 } $\mathrm{K}_{2} \mathrm{SO}_{4}\left(\mathrm{~kg} \mathrm{ha}^{-1}\right)$ & Tajuk & Akar & Total \\
\hline 0 & $4.98 \pm 0.55$ & $1.97 \pm 0.43$ & $6.96 \pm 0.87$ \\
$249.1(1 / 4 \mathrm{x})$ & $7.92 \pm 0.39$ & $2.34 \pm 0.26$ & $10.26 \pm 0.35$ \\
$498.2(1 / 2 \mathrm{x})$ & $9.45 \pm 1.69$ & $2.60 \pm 0.42$ & $12.05 \pm 2.00$ \\
$747.3(3 / 4 \mathrm{x})$ & $10.26 \pm 1.15$ & $2.99 \pm 0.29$ & $13.25 \pm 1.39$ \\
$996.4(\mathrm{X})$ & $10.93 \pm 1.90$ & $3.13 \pm 0.58$ & $14.06 \pm 2.40$ \\
$\mathrm{SS}$ error & 33.75 & 3.42 & 50.91 \\
Respon & $\mathrm{L}^{* *} \mathrm{Q}^{*}$ & $\mathrm{~L}^{* *}$ & $\mathrm{~L}^{* *} \mathrm{Q}^{*}$ \\
\hline Keterangan: Uji F untuk melihat pengaruh pembuatan status hara K tanah * $=$ nyatapada $\mathrm{P}<0.05 ; * *=$ sangat nyata \\
\multicolumn{3}{l}{ pada $\mathrm{P}<0.01 ;$ tn $=$ tidak nyata; $\mathrm{L}=$ linier pada uji lanjut polinomial, Q $=$ kuadratik pada uji lanjut } \\
polinomial.
\end{tabular}


Peningkatan status $\mathrm{K}$ tanah dengan penambahan pupuk $\mathrm{K}_{2} \mathrm{SO}_{4}$ meningkatkan kandungan $\mathrm{K}$ tajuk secara linier dan bobot kering tajuk secara kuadratik (Gambar 2). Respon tersebut mengindikasikan bahwa hara dari pupuk telah berubah menjadi hara tanah selama masa inkubasi sehingga tersedia dan dapat diserap oleh tanaman. Namun, hara $\mathrm{K}$ yang diserap tanaman tidak semua digunakan untuk pertumbuhan tanaman. Hara $\mathrm{K}$ umumnya diserap tanaman dalam jumlah yang lebih tinggi atau melebihi kebutuhan tanaman. Bobot kering tajuk mencapai maksimum ketika kandungan $\mathrm{K}$ tajuk berada pada kisaran $15-16 \%$.

\section{Korelasi Nilai $K$ Tanah dengan Bobot Kering Biomas}

Umumnya nilai $\mathrm{K}$ tanah terekstrak dari lima metode ekstraksi meningkat sejalan dengan peningkatan status $\mathrm{K}$ (Gambar 3). Hal ini menunjukkan perlakuan larutan $\mathrm{K}_{2} \mathrm{SO}_{4}$, telah mampu menghasilkan respons linier dari nilai $\mathrm{K}$ tanah terekstrak. Nilai koefisien korelasi 5 metode ekstraksi dengan $\mathrm{K}$ tanah terekstrak adalah 0.80-0.95 (Tabel 4). Hal tersebut menunjukkan bahwa hubungan antara $\mathrm{K}$ tanah terekstrak dengan perlakuan status $\mathrm{K}$ tanah memiliki asosiasi yang tinggi. Nilai korelasi tertinggi adalah metode ekstraksi $\mathrm{NH}_{4} \mathrm{OAc}$, diikuti oleh $\mathrm{HCl} 25 \%$, Mechlich, Bray I dan Morgan Wolf.

Uji $\mathrm{K}$ tanah dapat digunakan sebagai dasar penentuan rekomendasi pemupukan apabila memiliki hubungan erat dengan respon hasil tanaman. Kemampuan pengekstrak bervariasi menurut jenis tanaman dan (Susila et al., 2010), oleh karenanya, uji korelasi dengan respon hasil relatif tanaman menjadi hal penting dalam menentukan metode pengekstrak terbaik.

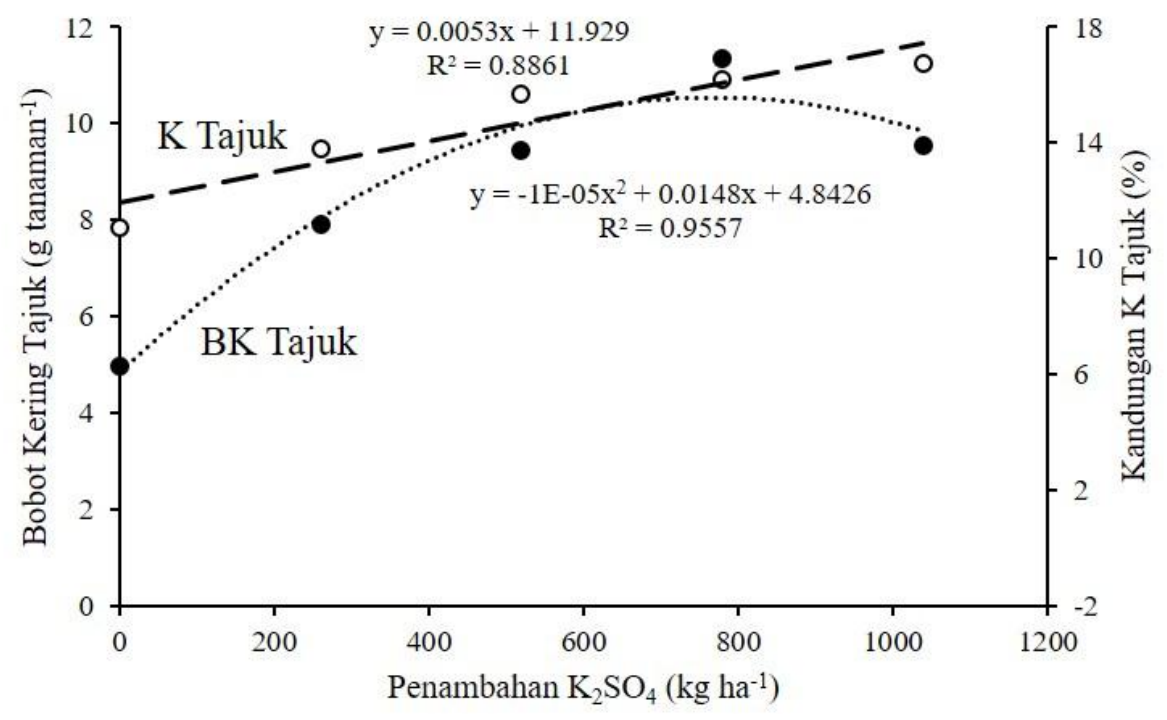

Gambar 2. Hubungan antara penambahan $\mathrm{K}_{2} \mathrm{SO}_{4}$ tanah dengan kandungan $\mathrm{K}$ tajuk dan bobot kering (BK) tajuk tanaman tomat di Tajur, Bogor pada tanah Andisol asal Pasirsarongge Cianjur. 

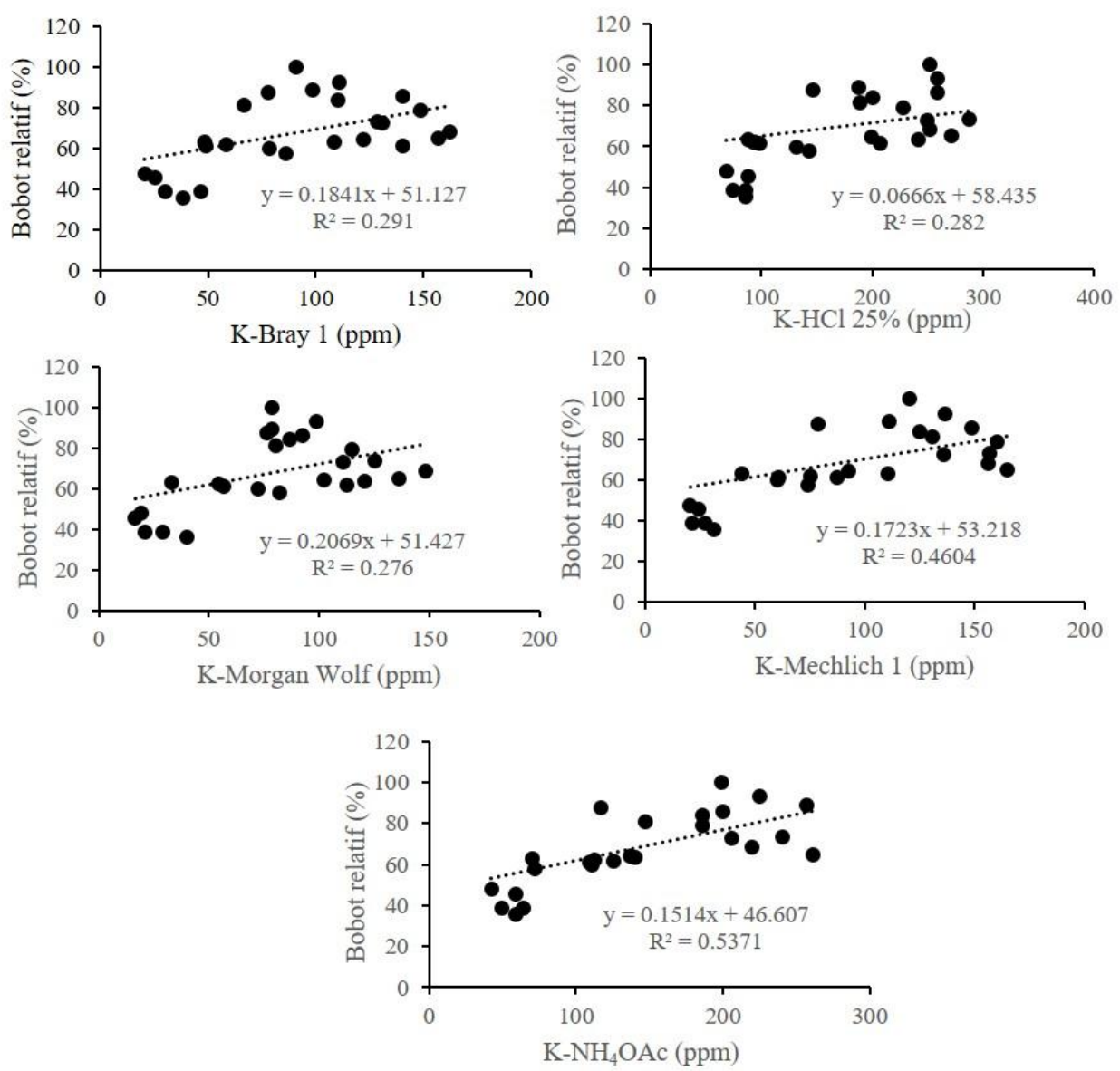

Gambar 3. Hubungan antara ekstraksi K Bray 1, $\mathrm{HCl} 25 \%$, Morgan Wolf, Mechlich 1 dan $\mathrm{NH}_{4} \mathrm{OAc}$ pada tanah Andisol Pasirsarongge dengan hasil bobot kering relatif (\%) tomat di Tajur, Bogor.

Tabel 4. Hasil relatif bobot kering biomas dan Nilai $\mathrm{K}$ tanah terekstrak Bray 1, $\mathrm{HCl} 25 \%$, Morgan Wolf, Mechlich 1 dan $\mathrm{NH}_{4} \mathrm{OAc}$ pada berbagai status $\mathrm{K}$ tanah Andisols Pasirsarongge, Cianjur

\begin{tabular}{|c|c|c|c|c|c|c|}
\hline \multirow{2}{*}{$\begin{array}{l}\text { Status K Tanah dengan } \\
\text { Penambahan K2SO4 } \\
\left(\mathrm{kg} \mathrm{ha}^{-1}\right)\end{array}$} & \multirow{2}{*}{$\begin{array}{l}\text { Hasil } \\
\text { Relatif } \\
\text { Bobot } \\
\text { Kering } \\
\text { Biomass } \\
(\%) \\
\end{array}$} & \multicolumn{5}{|c|}{ Nilai K Terekstrak ppm } \\
\hline & & Bray I & $\mathrm{HCl} 25 \%$ & $\begin{array}{c}\text { Morgan } \\
\text { Wolf }\end{array}$ & $\begin{array}{c}\text { Mechlich } \\
1\end{array}$ & $\mathrm{NH}_{4} \mathrm{OAc}$ \\
\hline Sangat Rendah (0) & $\begin{array}{l}41.32 \pm \\
5.18\end{array}$ & $\begin{array}{l}32.46 \\
\pm 10.34\end{array}$ & $\begin{array}{l}80.47 \pm \\
8.45\end{array}$ & $\begin{array}{l}25.11 \pm \\
4.42\end{array}$ & $\begin{array}{l}25.10 \pm \\
4.42\end{array}$ & $\begin{array}{l}54.77 \pm \\
8.63\end{array}$ \\
\hline Rendah (249.1) & $\begin{array}{l}60.90 \pm \\
2.05\end{array}$ & $\begin{array}{l}64.20 \pm \\
17.31\end{array}$ & $\begin{array}{l}111.12 \pm \\
24.83\end{array}$ & $\begin{array}{l}59.73 \pm \\
18.89\end{array}$ & $\begin{array}{l}62.99 \pm \\
12.78\end{array}$ & $\begin{array}{l}94.98 \pm \\
21.85\end{array}$ \\
\hline Sedang (498.2) & $\begin{array}{l}71.54 \\
\pm 11.84\end{array}$ & $\begin{array}{l}103.24 \pm \\
30.66\end{array}$ & $\begin{array}{l}196.41 \pm \\
34.47\end{array}$ & $\begin{array}{l}98.43 \pm \\
19.41\end{array}$ & $\begin{array}{l}99.83 \pm \\
20.74\end{array}$ & $\begin{array}{l}133.51 \pm \\
12.20\end{array}$ \\
\hline Tinggi (747.3) & $\begin{array}{l}78.66 \pm \\
8.22\end{array}$ & $\begin{array}{l}130.14 \pm \\
26.09\end{array}$ & $\begin{array}{l}223.44 \pm \\
28.68\end{array}$ & $\begin{array}{l}107.90 \pm \\
27.44\end{array}$ & $\begin{array}{l}137.70 \pm \\
20.98\end{array}$ & $\begin{array}{l}210.91 \pm \\
29.35\end{array}$ \\
\hline Sangat Tinggi (996.4) & $\begin{array}{l}83.47 \\
\pm 14.26 \\
\end{array}$ & $\begin{array}{l}125.51 \pm \\
25.71\end{array}$ & $\begin{array}{l}265.73 \pm \\
14.14 \\
\end{array}$ & $\begin{array}{l}106.20 \pm \\
23.71\end{array}$ & $\begin{array}{l}145.36 \pm \\
17.47 \\
\end{array}$ & $\begin{array}{l}225.21 \pm \\
26.41\end{array}$ \\
\hline $\begin{array}{l}\text { Koefisien korelasi } \\
\text { (bobot kering) }\end{array}$ & & $0.55 * *$ & $0.69 * *$ & $0.53 * *$ & $0.74 * *$ & $0.75 * *$ \\
\hline
\end{tabular}


Lima pengekstrak yakni, $\mathrm{NH}_{4} \mathrm{OAc}$, Mechlich, $\mathrm{HCl} 25 \%$, Bray 1 dan Morgan Wolf memiliki nilai koefisien korelasi dengan asosiasi yang tinggi dengan bobot kering relatif tanaman tomat (Tabel 4). Metode $\mathrm{NH}_{4} \mathrm{OAc}$ memiliki nilai koefisien korelasi tertinggi sehingga direkomendasikan sebagai pilihan terbaik sebagai pengekstrak $\mathrm{K}$ tanah Andisol untuk tanaman tomat di dataran tinggi. Namun demikian, karena kualitas tanah Andisol bisa berbeda dan mungkin dapat berubah seiring dengan waktu, lokasi, perbedaan vegetasi dan bahan induknya (Prasetya et al., 2012; Wibisono et al., 2016), maka pengujian lebih lanjut terhadap varian tanah Andisol lainnya masih diperlukan pada masa mendatang.

\section{KESIMPULAN}

Pembuatan status $\mathrm{K}$ tanah dengan menggunakan pupuk kalium sulfat $\left(\mathrm{K}_{2} \mathrm{SO}_{4}\right)$ dapat meningkatkan status $\mathrm{K}$ tanah Andisol sub grup Thaptic Melanaquands Pasirsarongge. Peningkatan status $\mathrm{K}$ tanah memberikan respons pertumbuhan vegetatif dan bobot kering tanaman tomat yang meningkat secara kuadratik dimana status $\mathrm{K}$ tinggi memberikan respon terbaik. Terdapat korelasi dengan tingkat asosiasi tinggi antara nilai $\mathrm{K}$ tanah dan bobot kering relatif pada metode ekstraksi $\mathrm{NH}_{4} \mathrm{OAC}$, Mechlich dan $\mathrm{HCl}$ $25 \%$ dengan nilai koefisien korelasi berturutturut adalah $0.75,0.74$, dan $0.69 . \mathrm{NH}_{4} \mathrm{OAC}$ merupakan metode ekstraksi terbaik untuk mengekstrak $\mathrm{K}$ tanah dan untuk menduga kebutuhan pupuk $\mathrm{K}$ tanaman tomat pada tanah Andisol dataran tinggi.

\section{DAFTAR PUSTAKA}

Amisnaipa, A.D. Susila, R. Situmorang, D.W. Purnomo. 2009. Penentuan kebutuhan pupuk kalium untuk budidaya tomat menggunakan irigasi tetes dan mulsa polyethylene. J. Agron. Indonesia 37(2): 115-122.

Amisnaipa, A.D. Susila, S. Susanto, D. Nursyamsi. 2014. Determination of extraction P method on Inceptisols soil for chili (Capsicum annuum L.). J. Hort. 24(1): 42-48.

[Balittanah] Balai Penelitian Tanah. 2005. Petunjuk teknis kalibrasi Uji $\mathrm{P}$ dan $\mathrm{K}$ tanah. Badan Penelitian dan Pengembangan Pertanian RI. Bogor.

[DITJEN HORTI] Direktorat Jenderal Hortikultura. 2017. Data Produksi, Luas Panen dan Produktivitas Sayuran di Indonesia. http://www.pertanian.go.id/ Indikator/tabel-2-prod-lspn-prodvitashorti.pdf. [29 Maret 2017].

Faranso, D., A.D. Susila. 2015. Rekomendasi pemupukan fosfor pada budidaya caisin (Brassica rapa L. cv. caisin) di tanah Andosol. J. Hort. Indonesia. 6(3): 135143.

Huda, A.N., W.B. Suwarno, A. Maharijaya. 2018. Respon delapan genotipe melon (Cucumis melo L.) terhadap perlakuan KNO3. J. Hort. Indonesia. 9(2): 84-92.

Izhar, L., A.D. Susila, B.S. Purwoko, A. Sutandi, I.W. Mangku. 2012. Penentuan metode terbaik uji fosfor untuk tanaman tomat pada tanah Inceptisols. J. Hort. 22(2): 139-147.

Izhar, L., A.D. Susila, B.S. Purwoko, A. Sutandi, I.W. Mangku. 2013. Penentuan metode terbaik uji kalium untuk tanaman tomat pada tanah Inceptisols. J. Hort. 23(3): 218-224.

Kasno, A., A.S. Ibrahim A. Rahman. 2013. Pengelolaan hara tanah dan peningkatan pendapatan petani dalam pola tanam sayuran dataran tinggi di Kopeng dan Buntu. hal. 193-200. Dalam L.R. Widowati (eds). Prosiding Seminar Nasional Peningkatan Produktivitas Sayuran Dataran Tinggi. Balai Besar Penelitian dan Pengembangan Sumberdaya Lahan Pertanian, Kementerian Pertanian.

Kasno, A., I.W. Suastika. 2017. Pengekstrak, status dan dosis pupuk kalium untuk padi gogo pada Hapludults, Braja Selebah, Kabupaten Lampung Timur. Jurnal Tanah dan Iklim. 41(1): 61-68. 
Maynard, E.T., I.S. Calsoyas, J. Malecki. 2016. Potassium applications and yellow shoulder disorder of tomatoes in high tunnels. Milwest Vegetables Trial Report, Purdue University. Purdue USA.

Nurtika, N. 2009. Respon tanaman tomat terhadap penggunaan pupuk majemuk NPK 15-15-15 pada tanah latosol pada musim kemarau. J. Hort. 19(1): 40-48.

Prasetya, B., S. Prijono, Y. Widjiawati. 2012. Vegetasi pohon hutan memperbaiki kualitas tanah Andisol-Ngabab. J. Indonesian Green Technol. 1(1): 1-6.

Purwati, E. 2009. Daya hasil tomat hibrida (F1) di dataran medium. J. Hort. 19(2): 125-130.

Sari, N.P., T.I. Santoso, S. Mawardi. 2013. Sebaran tingkat kesuburan tanah pada perkebunan rakyat kopi arabika di DataranTinggi Ijen-Raung menurut ketinggian tempat dan tanaman penaung. Pelita Perkebunan. 29(2): 93107.

Soil Survey Staff. 2014. KunciTaksonomi Tanah. Edisi Ketiga, 2015. Balai Besar Penelitian dan Pengembangan Sumberdaya Lahan Pertanian, Badan Penelitian dan Pengembangan Pertanian.

Suganda, H., N.L. Nurida. 2013. Prediksi dan tingkat bahaya erosi pada lahan usaha tani pengunungan di Kabupaten Temanggung Jawa Tengah. Dalam L.R. Widowati. (eds). Prosiding Seminar Nasional Peningkatan Produktivitas Sayuran Dataran Tinggi. Balai Besar Penelitian dan Pengembangan Sumberdaya Lahan Pertanian, Kementerian Pertanian.
Susila, A.D., J.K. Kartika, T. Prasetio, M.P. Palada. 2010. Fertilizer recommendation: correlation and calibration study of soil $\mathrm{P}$ test for yardlong bean (Vigna unguilata L.) on ultisols in NanggengBogor. J. Agron. Indonesia. 38(3): 225231.

Subhan, N. Nurtika, N. Gunadi. 2009. Respons tanaman tomat terhadap penggunaan pupuk majemuk NPK 15-15-15 pada tanah Latosol pada musim kemarau. J. Hort. 19(1): 40-48.

Sukarman, A. Dariah. 2014. Tanah Andosol di Indonesia. Balai Besar Penelitian dan Pengembangan Sumberdaya Lahan Pertanian. Bogor.

Syafruddin. 2008. Rekomendasi pemupukan $\mathrm{P}$ untuk tanaman jagung (Zea mays L.) pada tanah Inceptisols menggunakan pendekatan uji tanah. J. Tanah Tropika. 13(2): 95-102.

Wibisono, M.G., Sudarsono, Darmawan. 2016. Characteristics of Andisols of northeast Gunung Gede, West Java with Breccia and volcanic mudflow parent materials. J. Tanah dan Iklim. 40(1): 61-70.

Widyanti, A.S., A.D. Susila. 2015. Rekomendasi Pemupukan Kalium pada Budi Daya Cabai Merah Besar (Capscicum annuum L.) di Inceptisols Dramaga. J. Hort. Indonesia. 6(2): 6574.

Zhang, Y., K. Suzuki, H. Liu, A. Nukaya, Y. Kiriiwa. 2018. Fruit yellow-shoulder disorder as related to mineral element uptake of tomatoes grown in high temperature. Scientia Horticulturae. 242: 25-29. 